\title{
膀胱腫瘍に打ける非腫瘍部生検の意義
}

\author{
北海道大学医学部泌尿器科学教室 (主任：小柳知彦教授) \\ 高橋 和明 坂下 茂夫 丸 彰夫 小柳 知彦
}

\section{CLINICAL SIGNIFICANCE OF MULTIPLE BIOPSIES OF NONTUMOROUS BLADDER MUCOSA IN PATIENTS WITH BLADDER CANCER}

\author{
Kazuaki Takahashi, Shigeo Sakashita, Akio Maru and Tomohiko Koyanagi \\ Department of Urology, Hokkaido University School of Medicine
}

(Director: Prof. T. Koyanagi)

\begin{abstract}
Multiple biopsy specimens obtained from nontumorous bladder mucosa were investigated histologically. An average of 3.6 specimens was taken in 142 transurethral resection operations for 112 patients with bladder cancer. The histological categories used were normal epithelium, metaplasia, hyperplasia and G1-G3 dysplasia.

Thirty-seven patients $(27.7 \%)$ had G2<dysplasia within normal looking bladder mucosa. In patients with high grade bladder cancer, the incidence of the association with dysplasia was $51.7 \%$, which was significantly higher than the rates in patients with low or moderate grade bladder cancer $(\mathrm{p}<0.05)$.

The tumor recurrence was observed in 45 patients of 102 patients who were followed with bladder preservation. The recurrence was seen in 13 of 19 patients $(68.4 \%)$ with mucosal dysplasia in the previous operation. The rate was significantly higher than $38.6 \%$ in patients without dysplasia $(\mathrm{p}<0.05)$.

Thus, the epithelial dysplasia seen in nontumorous bladder mucosa were associated with higher grade bladder tumors more often, and the histology of multiple biopsy specimens might be one of predictors for tumor recurrence in near future.
\end{abstract}

要旨：膀胖腫瘍112例に対して行なった142回の経尿道的切除術の際に, 平均 3.6 カ所の非腫瘍部生検を行 い, 異常な上皮細胞の有無を検討した。非腫瘍部の上皮異形成を G1, G2, G3に 3 分し, G2 以上の異形 成上皮と腫瑒の異型度と再発との関係を検討した。

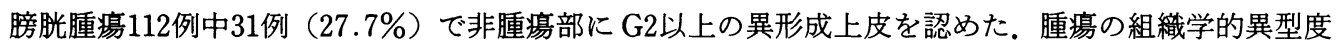
が G3の症例では，29例中15例 (51.7\%) で非腫瘍部に G2 以上の異形成を認め，G1の31例中 3 例 (9.7\%) に比べ高頻度に異形成上皮がみられ（p<0.01），G0の 9 例中 1 例 (11.1\%)，G2の 43例中 12 例 (27.9\%) に比べても高頻度であった（ $\mathrm{p}<0.05)$.

膀胱全摘術を受けた症例を除けば，経過観察中腫怚の膀脱内再発がみられたのは102例中45例である が，非腫崵部に G2以上の異形成を認めた19例中13例 $(68.4 \%)$ に再発がみられ，G2以上の異形成の認め なかった83例中 32 例の再発率 $(38.6 \%)$ に比べ高かった（p<0.05）.

したがって, 膀脂腫瘍患者の非腫場部生検で異形成上皮の存在は, 腫崵の悪性度と再発の指標になり らると考えられた。

\section{緒 言}

膀胱腫瘍においては，肉眼的あるいは内視鏡的に正 常に見える非腫瘍部の上皮細胞にもさまざまな変化が みられることが，1950年代の前半に見出されてい る ${ }^{12)}$ 。このよらな上皮内に限局した病変は, 異形成 (dysplasia) あるいは上皮内癌（carcinoma in situ） と今日呼ばれている。膀胱腫瘍の自然経過とこれらの 腫瘍に随伴した非腫瘍部の上皮内病変との関係につい ては，膀胱全摘標本あるいは経尿道的非腫場部生検組 織を用いて検討されてきた。しかし，異形成あるいは 
上皮内癌の定義や性格づけは，臨床的にも，病理組織 学的にも確定していないのが現状である ${ }^{3)}$.

我々は1982年から膀羘腫瘍における経尿道的膀羘腫 瘍切除 (以下 TUR-BT) の際, 同時に非腫瘍部生検を 積極的に行なってきた。ここでは，その得られた非腫 瘍部生検組織像之腫瘍部の組織学的異型度, 深達度, および臨床治療経過との関係を解析し, 膀胱腫瘍に括 ける非腫瘍部生検の臨床的意義を検討した。

\section{対象および方法}

北海道大学泌尿器科において，1982年から1986年ま での 5 年間に, 内視鏡的隆起性病変を認めた膀胱腫瘍 患者で, TUR-BT と同時に非腫瘍部生検を行なった 112名を検討の対象とした。患者の性別は男79名, 女33 名で, 年齢は28歳から88歳で平均年龄61.0歳であった。 切除された膀胖腫瘍はいずれる組織学的に移行上皮癌 または移行上皮癌十扁平上皮癌と確定したものであっ た。

生検は内視鏡による観察で正常と思われる粘膜を生 検鉗子にて採取した。その部位は主に膀羘三角部，後 壁, 左右側壁, 頂部, おょび男性後部尿道粘膜であっ

図 11 回の手術における生検部位数

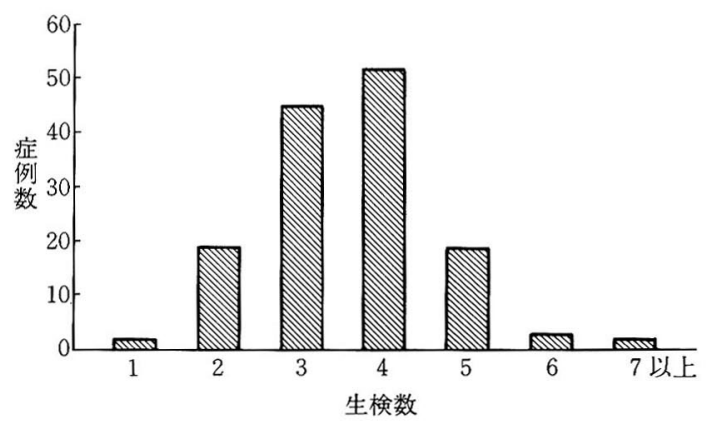

図 2 非腫瘍部の G1異形成. $\mathrm{HE}$ 染色 ( $\times 180)$

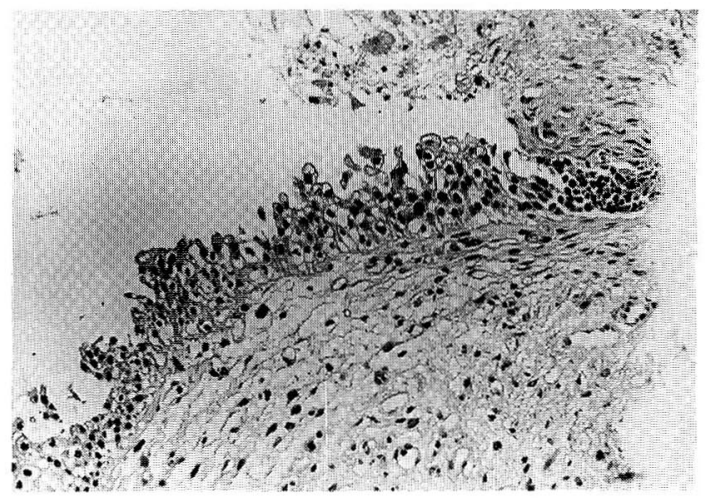

た。今回の非腫瘍部生検の検討では腫瘍部の近接部の 生検組織は除外した. 生検回数は初回の非腫瘍部生検 が112回, 再発後 2 回目以上の生検が30回で, 合計142 回であった。

腫湯近接部をのぞいた非腫場部生検で採取された生 検組織総数は514個であり, 1 回の手術あたりの生検部 位数を図 1 に示した。一回の手術あたり 4 力所生検さ れた場合が最も多く, 平均 3.6 所の粘膜が採取された.

組織学的所見は, 正常, 化生, 過形成, 異形成に分 けた. 異形成以外は日本泌尿器科学会, 病理学会によ る膀胱癌取扱規約 ${ }^{4}$ に従い判定した。異形成上皮につ いてはNagy $5^{3)}$ の分類を従い，その構成細胞の異型 度と組織構築から 3 種に分類し, 異型度の低いほうか ら高い順に G1，G2，G3とした。 それぞれの代表的な 組織像を図 2 図 4 亿示した。 G3異形成は, 組織学的 には日本泌尿器科学会, 病理学会による膀胱癌取扱い

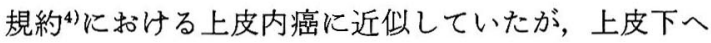
の浸潤は示さないものとした。同一症例で化生と異形 成，過形成と異形成が存在する場合は異形成とした。

図 3 非腫瘍部の G2異形成. HE 染色 $(\times 180)$

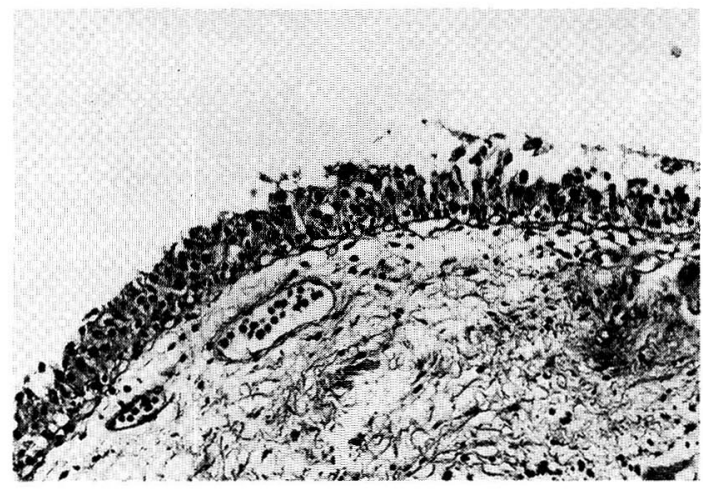

図 4 非腫場部の G3異形成. HE 染色 $(\times 180)$

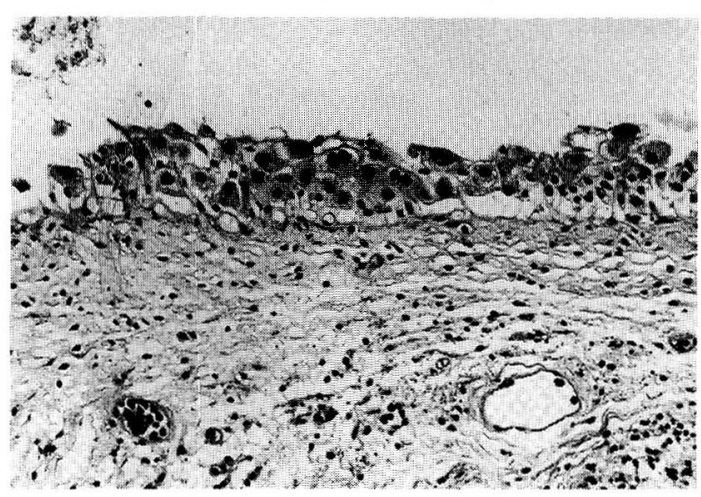


非腫場部生検組織像のらち, とくに G2, G3異形成の 存在に焦点を絞り, 以下にあげた膀胱腫瘍の組織学的, 臨床的な項目と対比し検討した。すなわち，日本泌尿 器科学会, 病理学会による膀胱癌取扱い規約 ${ }^{4}$ による 腫瘍の組織学的異型度分類, 腫崵の組織学的深達度, 腫瘍の再発と非腫瘍部の $\mathrm{G} 2, \mathrm{G} 3$ 異形成の存在との関 連を解析した。尚，2つ以上の異なった異型度を示す 腫瘍組織が混在する場合, 異型度の高い方をその腫瘍 の異型度とした。解析には $\chi^{2}$ 検定を用い, $\mathrm{p}<0.05 を$ 有 意差ありとした。

\section{結 果}

1. 非腫瘍部生検組織像

採取された514のうち, 上皮の剝脱や機械的な損傷な どにより組織学的診断が困難であった76個の標本を除 いた438個でその組織像を判定することができた。初回 および再発時の非腫瘍部生検症例合わせて142例のう ち,すべて正常組織像を示したのは43例であり, 残り

表 1 非腫瘍部生検に打ける組織像

\begin{tabular}{c|r|c}
\hline 非腫瘍部組織像 & 例数 & \multicolumn{1}{c}{$(\%)$} \\
\hline 正常上皮のみ & 43 & $(30.3 \%)$ \\
化生上皮まで & 4 & $(2.8 \%)$ \\
過形成上皮 & 10 & $(7.0 \%)$ \\
異 形成上皮 & 85 & $(59.9 \%)$ \\
\hline 計 & 142 & \\
\hline
\end{tabular}

表 2 非腫瘍部異形成上皮の分類と例数

\begin{tabular}{c|c}
\hline 異形成上皮 & \\
\hline G 1 & 44 \\
G 2 & 27 \\
G 3 & 14 \\
\hline 計 & 85 \\
\hline
\end{tabular}

表 3 腫瘍の組織学的異型度と非腫瘍部生検組織像

\begin{tabular}{|c|c|c|c|}
\hline \multirow{2}{*}{\multicolumn{2}{|c|}{ 腫瘍の異型度 }} & \multicolumn{2}{|c|}{ 非腫瘍部の G 2 扰よび $\mathrm{G} 3$ 異形成 } \\
\hline & & \multirow{2}{*}{$\frac{\text { あり（\%） }}{1(11.1 \%)}$} & \multirow{2}{*}{$\frac{\text { な ᄂ }}{8}$} \\
\hline G 0 & $N=9$ & & \\
\hline G 1 & $\mathrm{~N}=31$ & $3(9.7 \%)$ & 28 \\
\hline G 2 & $\mathrm{~N}=43$ & $12(27.9 \%)$ & 31 \\
\hline G 3 & $\mathrm{~N}=29$ & $15(51.4 \%)$ & 14 \\
\hline 計 & 112 & $31(27.7 \%)$ & 81 \\
\hline$\chi^{2}$ 検定 & \multicolumn{3}{|c|}{$\begin{array}{l}p<0.01: G 1-G 3, \\
p<0.05: G 0-G 3, \text { G } 2-G 3 \\
p<0.1: G 1-G 2\end{array}$} \\
\hline
\end{tabular}

99例では 1 カ所以上の非腫瘍部粘膜に非正常上皮の出 現が観察された。その内分けは，移行上皮以外への化 生のみがみられたのが 4 例，過形成上皮のみが観察さ れたのが10例であり，85例では異形成上皮が観察され た.したがって, 非腫瘍部に 1 力所以上の異形成上皮 が出現した頻度は $59.9 \%$ であった(表 1 ). 異形成上皮 の異型度分類では, G1異形成が44例と最も多く, G2異 形成が27例, G3 異形成が14例にみられた。結局, 臨床 的に問題となりらる $\mathrm{G} 2, \mathrm{G} 3$ 異形成は, 合わせて41例 (28.9\%) に観察されたことになる. 生検数でみると, 組織診断の可能であった 438 個の組織のうち 72 個 (16.4\%) に G2, G3の異形成上皮が出現していた.

2. 腫瘍部の組織学的異型度と非腫瘍部生検組織像 初回の非腫瘍部生検をうけた112例の腫瘍部の組織 学的異型度と非腫瘍部生検組織像の関係を表 2 , 表 3 に示した。腫瘍の組織学的異型度の内分けは, G0が 9 例, G1が31例, G2が43例, G3が29例であった. 非腫瘍 部に化生のみがみられたのは 4 例で, 過形成は10例に みられた。一方, 非腫瘍部に G2, G3異形成上皮の出現 がみられたのは，G0腫瘍では 1 例（11.1\%)，G1では 3 例 (9.7\%), G2では12例 (27.9\%), G3では15例 (51.7\%)であった。統計学的には，G3の腫瘍ではそれ 以外の腫瘍のいずれに比べても, 非腫瘍部に異形成上 皮の出現する頻度が高かった $(\mathrm{p}<0.05)$.

3. 腫瘍部の組織学的深達度と非腫瘍部生検組織像 初回の非腫瘍部生検をうけた112名について腫瘍部 の組織学的深達度と非腫場部生検組織像の関係を表 4 に示した。

腫瘍部の組織学的深達度別の症例数は, Ta が18例, T1が41例, T2が13例, T3が 3 例, CIS が 4 例, Tx が 33例であった. そのうち非腫瘍部生検にて G2, G3 異形 成の所見があったのは，それぞれ Taで 1 例 (5.6\%)， T1で 8 例 (19.5\%), T2で 6 例 (46.2\%), T3で 1 例

表 4 腫瘍の深達度と非腫瘍部生検組織像

\begin{tabular}{|c|c|c|c|}
\hline \multirow{2}{*}{\multicolumn{2}{|c|}{ 腫瘍の深達度 }} & \multicolumn{2}{|c|}{ 非腫瘍部の G 2 およびG 3 異形成 } \\
\hline & & \multirow{2}{*}{$\frac{\text { あり（\%） }}{1(5.6 \%)}$} & \multirow{2}{*}{$\frac{\text { な し }}{17}$} \\
\hline $\mathrm{T}$ a & $\mathrm{N}=18$ & & \\
\hline $\mathrm{T} 1$ & $N=41$ & $8(19.5 \%)$ & 33 \\
\hline $\mathrm{T} 2$ & $\mathrm{~N}=13$ & $6(46.2 \%)$ & 7 \\
\hline T 3 & $\mathrm{~N}=3$ & $1(33.3 \%)$ & 2 \\
\hline Tis & $N=4$ & $4(100.0 \%)$ & 0 \\
\hline $\mathrm{T} x$ & $\mathrm{~N}=33$ & $11(33.3 \%)$ & 22 \\
\hline$\chi^{2}$ 検定 & $\begin{array}{l}\mathrm{p}<0 \\
\mathrm{p}<0\end{array}$ & $\begin{array}{l}: \mathrm{T} \mathrm{a}-\mathrm{T} 2 \\
: \mathrm{T} 1-\mathrm{T} 2\end{array}$ & \\
\hline
\end{tabular}


(33.3\%) であり，このほか CIS で 4 例（100\%), Tx で11例(33.3\%)であった. CIS では, 症例数は少ない が非腫瘍部に G2，G3異形成が高頻度に出現した。 た，T2の腫瘍では，Taの主要に比べ非腫瘍部に G2, G3異形成の出現する頻度が高かった $(\mathrm{p}<0.01)$. その 他の組織学的深達度の間には異形成上皮の出現頻度に 有意差はなかった。

\section{4. 再発と非腫瘍部生検組織像}

非腫瘍部生検を実施した症例で, 膀胱摘除症例を除 き術後抗癌剤膀胼内注入療法を施行しながら再発の有 無を観察した症例は102例であった。このらち再発がみ られたのは45例 (44.1\%)であった。再発例において， 前回の経尿道的電気切除術の際に施行された非腫瑒部 生検で G2，G3異形成がみられたのは13例で，G2，G3 異形成がみられなかったのが32例であった。この結果， G2，G3異形成がみられた19例の再発率は68.4\%とな り，G2，G3異形成がみられなかった83例の再発率 $38.6 \%$ に比べ高率であった（ $\mathrm{p}<0.05 ）$ (表 5 ).

再発を理由として，2 回以上の非腫瘍部生検を行っ たのはのべ30例であるが，このうち21例では， 2 回目 の非腫瘍部生検組織像を初回のそれと比較し得た（表 6 ).腫瘍の組織像の比較で初回の組織学的異型度に比 べ悪化したのは10例で, 不変が11例であった。再発時 の非腫湟部の生検組織像を初回のそれと比べると, 新 たに G2, G3異形成上皮が出現したり, 異形成の程度が 進行したのは11例で, 不変は 9 例であった。腫癔の組 織学的異型度が悪化した 10 例中 6 例では非腫瘍部の組 織像は不変であり，また腫瘍の組織像が不変であった 11例中非腫瘍部の組織像が不変であったのはわずか 3 例であった。この結果, 個々の症例で腫瘍の組織学的

表 5 非腫瘍部の G 2 および G 3 異形成と その後の再発

\begin{tabular}{c|c|c|c}
\hline 非腫瘍部組織像 & 例数 & 再発あり（\%) & $\chi^{2}$ 検定 \\
\hline 異形成あり & 19 & $13(68.4 \%)$ & $\mathrm{p}<0.05$ \\
異形成なし & 83 & $32(38.6 \%)$ & \\
\hline 計 & 102 & $45(44.1 \%)$ & \\
\hline
\end{tabular}

$*$ : 膀胱全摘除術施行例を除く

表 6 再発症例に扣ける非腫瘍部生検組織像の変化

\begin{tabular}{l|c|c|c}
\hline \multirow{2}{*}{ 腫瘍部異型度 } & \multicolumn{3}{|c}{ 非腫痬部生検組織像 } \\
\cline { 3 - 5 } & grade up & grade down & no change \\
\hline grade up $\quad \mathrm{N}=10$ & 4 & 0 & 6 \\
no change $\mathrm{N}=11$ & 7 & 1 & 3 \\
\hline
\end{tabular}

異型度の悪化と非腫崲部の組織像の変化の間には特別 な関係を見いだすことはできなかった，再発部位にお ける以前の非腫瘍部生検組織像を比べてみたが（部 位：膀胼癌取扱い規約による), 評価可能な24例中正常 が12例, G1異形成が 5 例, G2異形成が 7 例で特別な傾 向を認めなかった。

非腫場部生検は, 再発や多発の性質を持つ膀胖腫瘍 に拈いて, 前癌状態之言らべき異常な上皮の早期発見 を主な目的として開始された方法である。特に異形成 上皮の出現と腫場の再発や進行の関係が明らかとなれ ば, 非腫瘍部生検は治療方針の決定に有力な根拠を与 える事になり, 膀脱全摘標本のマッピングによる非腫 瘍部の組織検査とは異なる意義を持つと考えられる。 しかし, 膀胱癌の前癌病変の特定についてはもちろん のこと, 異形成上皮の定義についても議論が多いとこ ろである5). 本邦に打ける膀朕癌取扱い規約) において は，腫瘍様病変ないし異常上皮として上皮異形成がと りあげられているが，その定義あるいは分類について は明確とされていない。そこで, 本研究では異形成の 定義と分類は Nagy $ら^{3}$ に従い, 非腫場の異形成上皮 の出現のもつ臨床的意義を検討した.

今回の検討では異形成を, その程度から 3 分類した が, G1の異形成には正常上皮との区別が困難なものが あった。 また，G1の異形成はすでに述べられているよ $5 に(\text { Murphy, Tannebaum })^{677)}$, 上皮の変性, 再生あ るいは反応性の変化とも厳密に区別することは困難と 考光た。いっぽう，Murphy6) はG3の異形成を neoplastic としているが，本研究に扣いては，G2異形成と の境界は必ずしも明確でない場合があった。そこで, $\mathrm{G} 2$ 以上の異形成に焦点を絞り，G2抢よび G3異形成を 一群として検討対象にした。

採取された514個の標本の5ち，76個 (14.8\%) は組 織学的診断が困難であった。これらの標本では，上皮 の剝脱や，上皮が存在しても組織構築上の損傷が高度 であった。 上皮細胞の䟝奪は, 上皮内癌でみられるよ らな細胞間接着が弱い時に, 病変そのものの性質に起 因した減少とも考えられるが，人為的損傷と区別でき ないために判定から除外した。また，上皮細胞の損傷 は，人為的な原因によると考兄られ，特に，電気メス を用いた生検組織には組織診断の可能な標本は少な かった。したがって，非腫湯部生検の組織診断では, まず, 保存状態の良い標本をらることが重要であって, 注意深い組織の採取と取扱いが必要と考えられた。 
438個の非腫瘍部生検組織の検討で，72個（16.4\%） に G2以上の異形成があった。症例単位でみると, 初回 の検查112例中31例(27.7\%)，再発を含めればのべ142 例中41例 $(28.9 \%$ ）に異形成上皮が観察された。非腫 湯部生検で異形成上皮の出現頻度に関する従来の報告 では，その定義は必ずしも同一ではないが，20 $80 \%{ }^{8) \sim 13)}$ とされている. 今回の検討でも G1異形成を 含めば59.9\%の出現頻度であり, 従来の報告と近似し ていた. 腫瘍組織の異型度と非腫瘍部の G2以上の異型 上皮の出現には密接な関係がみられた。すなわち，G3

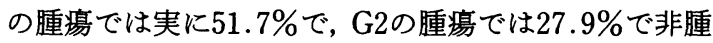
瘍部に G2以上の異形成を伴うことが判明した。これ は, G1における9.7\%の出現率に比べ高かった。 このよ らな G2以上の異形成上皮の存在が, 前癌状態と密接な 関係があるとすれば，腫瘍の再発の危険因子となりら る. 事実, 今回の 112 例中 45 例が，観察期間中に再発し たが，異形成を認めなかった83例中32例（38.6\%）が 再発したのに対して，異形成を認めた場合は19例中13 例 $(68.4 \%)$ と高率に再発した $(\mathrm{p}<0.05)$.

以上の成績から, 非腫瘍部の生検組織に G2 形成上皮をみとめることは, 腫瘍の組織学的異型度に 代表される悪性度と再発危険度の高いことが示してい ると言える。臨床的な側面から述べれば，非腫場部に 異形成上皮の存在は, 低分化型腫場の場合にはより強 力な治療を, 高分化型腫瘍ではより厳密な経過観察を 支持する根拠となると考兄られる。

しかし，G2以上の異形成上皮が，隆起性膀脱癌の前 癌状態か否かを今回の結果から断定するには，な颃不 十分と考兄られた。それは，異形成上皮から腫瘍への 発育過程を直接観察していないからである。今後は， 異形成上皮の定義をより明確にするためには，まず， 正常上皮と異形成上皮の細胞生物学的な相違を明確に する研究の進展が期待される.さらに, 膀胱内景の詳 細な地困を作製し, 非腫瘍部の異形成上皮とその後の 再発腫場の地理的関係を経時的に明らかにする必要が あろう。

\section{結 語}

1. 112例の膀胱腫瘍患者に142回の非腫瘍部生検を 施行した。初回の非腫瘍部生検で31例(27.7\%)に G2, G3異形成上皮がみとめられた。

2. 非腫瘍部の $\mathrm{G} 2, \mathrm{G} 3$ 異形成上皮の出現頻度は, 腫 瘍の組織学的異型度が高くなるほど高頻度であった $(\mathrm{p}<0.05)$.

3. 膀朕腫瘍の再発は, 非腫瘍部に G2, G3異形成上
皮のみられた $68.4 \%$, 異形成上皮のみられなかった $38.6 \%$ にられ, 前者の再発率が高かった $(\mathrm{p}<0.05)$.

4. したがって, 非腫瘍部に異形成上皮が存在するこ とは, 腫場の悪性度あるいは再発の危険に関して指標 となると思われた。

\section{文献}

1) Melicow, M.M.: Histological study of vesical urothelium intervention between gross neoplasms in total cystectomy. J. Urol., 68, 261 $-279,1952$.

2) Mashna, F.: Mucosal changes in relation to bladder tumor. Brit. J. Urol., 24, 344-351, 1952.

3) Nagy, G.K., Frable, W.J. and Murphy, W.M.: Classification of premalignant urothelial abnormalities: A Delphi study of the national bladder cancer collaborative group A. Path. Ann., Part 1. 17, 219-233, 1982.

4) 日本泌尿器科学会, 日本病理学会: 泌尿器科, 病 理. 膀脱癌取扱い規約. 第 1 版, 1980 .

5) Dean, P.J. and Murphy, W.M.: Carcinoma in situ and dysplasia of the bladder urothelium. World J. Urol., 5, 103-107, 1987.

6) Murphy, W.M. and Soloway, M.S.: Urothelial dysplasia. J. Urol., 127, 849-854, 1982.

7) Tannebaum, M., Romas, N. and Droller, M.: The pathobology of early urothelial cancer. Rd. Skinner, D.G. and Lieskovsky, G., Genitourinary Cancer, p. 55, Saunders CO., Philadelphia, 1988.

8) Soloway, M.S., Murphy, W., Rao, M.K. and Cox, C.: Serial multiple-site biopsies in patients with bladder cancer. J. Urol., 120, 57-59, 1978.

9) Wallace, D.M.A., Hindmarsh, J.R., Webb, J.N., Busuttil, A., Hargreave, T.B., Newsam, J.E. and Chisholm, G.D.: The role of multiple mucosal biopsies in the management of patients with nladder cancer. Brit. J. Urol., 51, 535-540, 1979.

10) Cooper, T.P., Wheelis, R.F., Correa, R. J. Jr., Gibbons, R.P., Mason, J.T. and Cummings, K. B.: Random mucosal biopsies in the evaluation of patients with carcinoma of the bladder. J. Urol., 117, 46-48, 1977.

11) Wolf, H. and Hojgaard, K.: Urothelial dysplasia in random mucosal biopsies from patients with bladder tumors. Scand. J. Urol. Nephrol., 14, 37-41, 1980.

12) Wolf, H. and Hojgaard, K.: Prognostic factors in local surgical treatment of invasive bladder cancer, with special reference to the presence of urothelial dysplasia. Cancer, 51, $1710-1715,1983$.

13）㐎木 喬, 滰川 浩, 香川 征, 黒川一男：膀胼腫 瘍における Multiple Mucosal Biopsy. 西日泌尿, 48, 733-736, 1986.

（1989年 1 月 10 日受理） 